\title{
Phospholipids and Cellular Division of Escherichia coli
}

\author{
By J. STÁRKA AND JIŘINA MORAVOVÁ \\ Laboratoire de Chimie Bactérienne, Centre National de la Recherche Scientifique, \\ Marseille ge, France
}

(Accepted for publication 5 November 1969)

\begin{abstract}
SUMMARY
Low doses of penicillin which inhibited division but permitted filament formation in Escherichia coli did not influence the total rate of phospholipid formation but altered the ratio of individual phospholipids to that characteristic of resting organisms: the filaments contained more cardiolipin and less phosphatidyl glycerol than normal exponentially dividing organisms. Addition of penicillinase to growing filaments restored both normal division and the normal phospholipid ratio. Filaments induced by u.v.-irradiation showed similar changes in phospholipid ratio. These findings suggest that phospholipids or their derivatives are directly involved in division.
\end{abstract}

\section{INTRODUCTION}

Filamentous forms of certain bacteria induced by different inhibitors of division can be used to study certain aspects of bacterial cytokinesis. We have described the properties of filaments formed by Escherichia coli в with a low concentration of penicillin (Stárka \& Moravová, I967). Penicillin (2.5 units/ml.) inhibit division completely but the synthesis of protein and nucleic acids continues at a normal rate. The filaments formed under these conditions contain several well-separated nuclei but septa are completely absent according to (I) electron microscopy of ultrathin sections of filaments and (2) the fact that each filament gives only one spheroplast with lysozyme and EDTA. Chemical composition of filament envelopes change as a result of penicillin action: after 60 min. cultivation with penicillin the contents of diaminopimelic acid and of hexosamines was about $25 \%$ lower than in untreated organisms. On the other hand, the kinetics of lysis of normal bacteria and filaments by lysozyme and EDTA were similar (J. Stárka, unpublished observations).

After addition of penicillinase, the filaments divide into rods of normal length. The reversion of filaments to normal rods by penicillinase can be stopped by chloramphenicol, mitomycin $\mathrm{C}$, actinomycin $\mathrm{D}$, nalidixic acid and other inhibitors of protein and nucleic acid synthesis. These results led us to the conclusion that (I) de novo synthesis of protein is essential for the division of filaments after removal of penicillin and that (2) the signal for septation is given by the replicating DNA (Stárka \& Moravová, 1967).

There are serious reasons to suppose that not only the wall but also the cytoplasmic membrane is involved in the final stage of division of bacteria. Cronan (I968) described an increase of cardiolipin accompanied by a decrease of phosphatidyl glycerol after the transition from exponential to stationary phase of growth of Escherichia coli. These phospholipids are present almost exclusively in the cytoplasmic membrane. Similar 
changes were reported by Bertsch, Bonsen \& Kornberg (1969) in the early stationary phase preceding the spore formation of Bacillus megaterium. These variations might either be expressions of metabolic shifts occurring in stationary cells, or they might reflect direct function of the membrane in the division process. We therefore thought it useful to see whether any change in phospholipid content occurs in growing but nondividing cells, i.e. during formation of filaments of $E$. coli which may be induced with penicillin or u.v.-radiation. The results are reported in this communication.

\section{METHODS}

Organisms and media. Escherichia coli B was maintained on nutrient agar (Difco). For each experiment an exponentially growing culture in glycerol-lactate (GL) medium (g./1.: NaCl, 3.0; $\mathrm{MgSO}_{4} .7 \mathrm{H}_{2} \mathrm{O}, 0.12 ; \mathrm{NH}_{4} \mathrm{Cl}, \mathrm{I} \cdot 0 ; \mathrm{CaCl}_{2}, 0.00 \mathrm{I} ; \mathrm{KH}_{2} \mathrm{PO}_{4}$, $0 \cdot \mathrm{I} 5 ; \mathrm{K}_{2} \mathrm{HPO}_{4}, 0 \cdot 35 ;$ neopeptone (Difco), $\mathrm{I} \cdot 0$; glycerol, $2 \cdot 0$; sodium-lactate, $8 \cdot 0$; distilled water; $\mathrm{pH} \mathrm{7.2)}$ was inoculated into the same medium and incubated at $37^{\circ}$ on a reciprocal shaker.

Growth measurements. Extinctions in a I cm. cell at $450 \mathrm{~m} \mu$ were measured in a Jean \& Constant spectrophotometer. A Petit-Salumbeni chamber, depth $0.04 \mathrm{~mm}$, calibrated with $0 \cdot$ IO units, corresponded to $0.9 \times 10^{8}$ normal organisms $/ \mathrm{ml}$.

Induction of filamentous growth by penicillin. Exponentially growing bacteria were supplemented with 2.5 units sodium benzyl penicillin $/ \mathrm{ml}$. (Spécilline G, I660 units/mg., kindly donated by Rhône-Poulenc Ltd., Paris). Samples for counting and extinction measurement were fixed with formol $(0.2 / 5 \mathrm{ml}$. culture). To reverse penicillin action, penicillinase (Bacto Penase, Difco) was added to about 100 units $/ \mathrm{ml}$. Filament formation and growth, as well as division after addition of penicillinase, was monitored by phase-contrast microscopy.

Extraction and estimation of phospholipids. Exponentially growing cells were inoculated in $200 \mathrm{ml}$. of GL medium containing about $2 \mu \mathrm{C}$ [ $\left.{ }^{32} \mathrm{P}\right]$ labelled phosphate $/ \mathrm{ml}$. (obtained from CEA, Gif-sur-Yvette). Samples (1 $5 \mathrm{ml}$.) were precipitated with $5 \mathrm{ml}$. $50 \%(\mathrm{w} / \mathrm{v})$ cold TCA, and the precipitate was washed twice on a membrane filter (Millipore, porosity $0.45 \mu \mathrm{m}$.) with $5 \%$ TCA and finally with water. The filters, with precipitate, were placed in $5 \mathrm{ml}$. of chloroform + methanol $(2+\mathrm{I}, \mathrm{v} / \mathrm{v})$ and allowed to stand at room temperature overnight. The extract was separated by filtration through membrane filter, placed in a scintillation vial, evaporated and redissolved in toluene scintillation solution ( $4^{\circ} \circ \mathrm{g}$. PPO and $0.5 \mathrm{~g}$. POPOP $\left./ 1\right)$. The samples were counted in a Mark I Nuclear Chicago instrument.

Separation of phospholipids. Phospholipids for chromatographic separation were extracted by two variant methods:

Extraction of intact bacteria (Kanemasa, Akamatsu \& Nojima, 1967). The sample culture was rapidly refrigerated, centrifuged at $7000 \mathrm{~g}$ in a refrigerated centrifuge and the sediment was extracted with chloroform + methanol $(2+\mathrm{I})$ three times. The combined supernatant fluid was evaporated in vacuo, redissolved in chloroform + methanol $(2+I)$ and subjected to Folch's diffusion procedure (Folch, Lees \& Sloan-Stanley, 1957). Dialysed extract was supplemented with methanol to original volume, partly evaporated and used for chromatography.

Extraction of perchloric acid-precipitated bacteria (Lubochinski, Meury \& Stolkowski, I965). A sample of culture was precipitated with cold perchloric acid (final conc. 
$0.3 \mathrm{~N}$ ) and rapidly cooled, bacteria were centrifuged at $7000 \mathrm{~g}$ at $4^{\circ}$, washed twice with $50 \mathrm{~mm}$-phosphate buffer $\mathrm{pH} 7 \cdot 0$ and the precipitate extracted and dialysed as in the first variant.

In all extracts total phosphorus content $/ \mathrm{ml}$. was then determined.

Thin-layer chromatography. Individual phospholipids were separated by thin-layer chromatography with Silica Gel G (E. Merck, A. G., Darmstadt, Germany) plates $0.25 \mathrm{~mm}$. thick and prepared as recommended by the manufacturer. Plates were airdried, activated by heating at $110^{\circ}$ for $30 \mathrm{~min}$. and stored overnight in a dessicator over $\mathrm{P}_{2} \mathrm{O}_{5}$ or $\mathrm{CaCl}_{2}$. The sample applied to the plate never contained more than $0.3 \mu$ mole phosphorus. For quantitative determinations, two-dimensional separations were most useful. The first solvent was chloroform + methanol + water $(70+25+4)$; after development plates were air-dried for 30 min., placed in a dessicator with $\mathrm{P}_{2} \mathrm{O}_{5}$ overnight, and run laterally in chloroform + methanol $+7 \mathrm{M}-\mathrm{NH}_{4} \mathrm{OH}(60+35+4)$. Dried plates were detected with iodine vapour and then sprayed with ninhydrin or with molybdenum blue reagent (Dittmer \& Lester, 1964). In some cases, radioactive phospholipids were located by autoradiography, using Kodak 'no screen' X-ray film. The spots were scraped from the plate and transferred quantitatively to scintillation vials containing scintillation liquid.

Phosphorus estimation. Total phosphorus in extracts containing phospholipids was carried out by the method of Bartlett (1958).

Ultraviolet irradiation. A $50 \mathrm{ml}$. sample of bacteria in GL medium was irradiated for $30 \mathrm{sec}$. $24 \mathrm{~cm}$. from a Mineralight UVS i I lamp. Bacteria (u.v.-irradiated) were cultivated in the dark.

Identification of phospholipids. The phospholipids were identified by their chromatographic behaviour compared with commercial standards. Cardiolipin (diphosphatidyl glycerol) was purchased from N.B.C., Cleveland, Ohio; phosphatidyl ethanolamine and phosphatidyl serine were from Koch-Light Laboratories, Ltd., Colnbrook, England. Phosphatidyl glycerol was a gift from Dr Ailhaud, C.N.R.S., Marseille. The solvents for chromatography were all reagent grade and were purified by the methods recommended by Rouser \& Flescher (1967).

\section{RESULTS}

Incorporation of ${ }^{32}[P]$ in lipid fraction of normal organisms and penicillin-induced filaments of Escherichia coli. Exponentially growing bacteria were incubated in $400 \mathrm{ml}$. of GL medium containing I $\mu \mathrm{C}\left[{ }^{32} \mathrm{P}\right] / \mathrm{ml}$. After I00 min., when OD $=0.20$, the culture was divided into two parts. One was supplemented with 2.5 units penicillin $/ \mathrm{ml}$, the other served as control. Samples $(20 \mathrm{ml}$.) were withdrawn at $20 \mathrm{~min}$. intervals for extraction of lipids, O.D. determination and counting. After $60 \mathrm{~min}$., penicillinase was added to induce division of filaments. Fig. I shows the amount of [ $\left.{ }^{32} \mathrm{P}\right]$ incorporated in chloroform-methanol fraction of lipids from samples of the two cultures: the rate of incorporation was not altered either by penicillin or by its removal with penicillinase. The rate of incorporation of phosphorus into the unfractionated phospholipids had the same slope as the rate of increase of optical density and both rates remained constant during the experiment.

Composition of phospholipids in filaments of Escherichia coli. Although the total 
phospholipids/turbidity unit did not change during inhibition of division by penicillin or its reversal by penicillinase, this experiment did not exclude the possibility that the relative amounts of individual phospholipids might have changed. Isotopically labelled

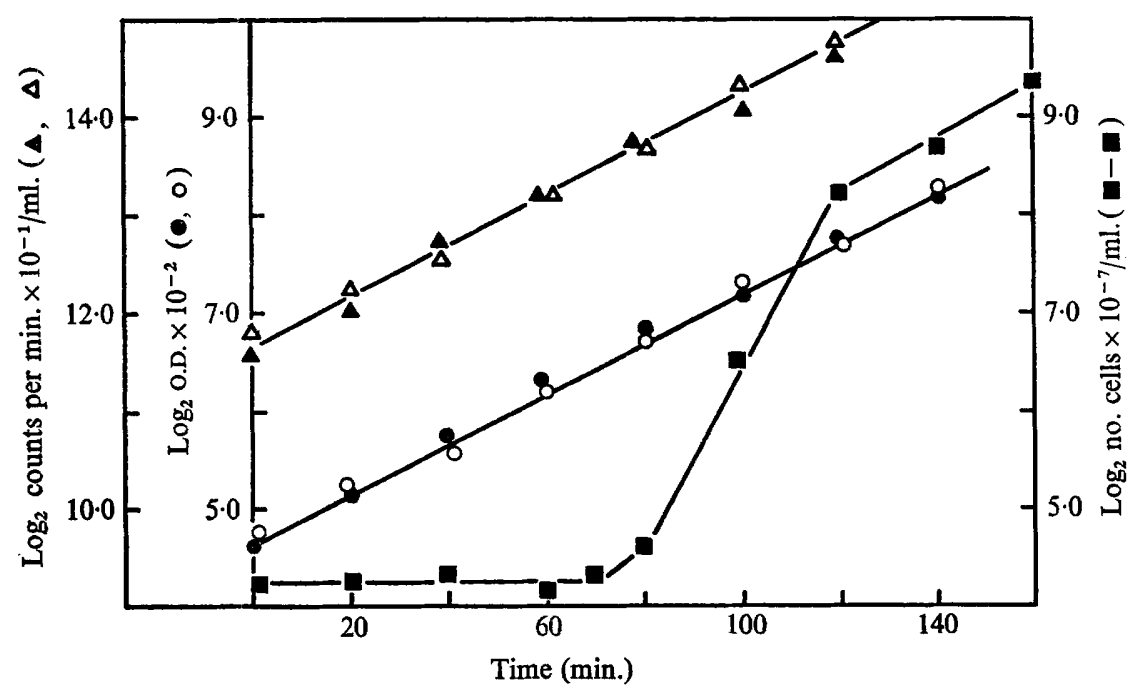

Fig. I. Incorporation of radioactive phosphorus in phospholipids of normal cells of Escherichia coli B (empty triangles) and of penicillin-induced filaments (full triangles). Penicillin was added at $\mathrm{o}$ min., and penicillinase at $60 \mathrm{~min}$. Optical density was measured in untreated control (empty circles) and in filaments (full circles). The number of cells treated with penicillin and with penicillinase was determined in a counting chamber (full squares).

Table I. Relative amounts of phospholipids detected in perchloric acid-treated extracts of Escherichia coli $B$

Per cent of total ${ }^{32} \mathrm{P}$ counts in phospholipids separated by thin-layer chromatography

\begin{tabular}{|c|c|c|c|c|}
\hline & Cardiolipin & $\begin{array}{l}\text { Phosphatidyl } \\
\text { glycerol }\end{array}$ & $\begin{array}{l}\text { Phosphatidyl } \\
\text { ethanolamine }\end{array}$ & $\begin{array}{l}\text { Phosphatidyl } \\
\text { serine }\end{array}$ \\
\hline Exponential bacteria & 0.35 & $22 \cdot 90$ & $72 \cdot 3 I$ & $4 \cdot 44$ \\
\hline Stationary bacteria & 3.39 & $12 \cdot 0$ & $8 I \cdot 46$ & $3 \cdot 17$ \\
\hline $\begin{array}{l}\text { Filaments after } 60 \mathrm{~min} \text {. } \\
\text { of penicillin action }\end{array}$ & $4 \cdot 82$ & $16 \cdot 75$ & $74 \cdot 0$ & 4.43 \\
\hline $\begin{array}{l}\text { Filaments after } 60 \mathrm{~min} . \\
\text { of penicillin }+25 \mathrm{~min} \text {. of } \\
\text { penicillinase }\end{array}$ & $3 \cdot 65$ & $17 \cdot 30$ & $74 \cdot 55$ & $4 \cdot 50$ \\
\hline $\begin{array}{l}\text { Filaments after } 60 \mathrm{~min} \text {. } \\
\text { of penicillin }+50 \mathrm{~min} \text {. of } \\
\text { penicillinase }\end{array}$ & $0 \cdot 28$ & $22 \cdot 62$ & $71 \cdot 95$ & $5 \cdot 15$ \\
\hline
\end{tabular}

phospholipids were therefore extracted from different phases of growth of filaments and normal rods. The arrangement of this experiment was essentially the same as described for Fig. I but $2 \mu \mathrm{C}$ of $\left[{ }^{32} \mathrm{P}\right] / \mathrm{ml}$. was present. Samples of untreated bacteria for extraction were withdrawn at O.D. $=0.35$ (exponential phase) and in the stationary phase. Filaments were analysed after $60 \mathrm{~min}$. of penicillin action. At that time penicillinase 
was added and samples of reverting filaments were examined after 25 and $50 \mathrm{~min}$. of further incubation.

After $60 \mathrm{~min}$. with penicillin all cells appeared as filaments about $10 \mu \mathrm{m}$. long; reversion of filaments to normal rods was practically completed $60 \mathrm{~min}$. after adding penicillinase. The rate of division was then the same as in the untreated control. Table I demonstrates that the relative amounts of radioactive phosphorus incorporated into phosphatidyl glycerol, cardiolipin, phosphatidyl ethanolamine and phosphatidyl serine in normal non-growing cells from the stationary phase and in exponentially growing filaments were practically identical. On the other hand, exponential normal cells contained relatively more phosphatidyl glycerol and less cardiolipin.

\section{Table 2. Relative amounts of phospholipids extracted from Escherichia coli $B$ without precipitation by perchloric acid}

Per"cent of total ${ }^{32} \mathrm{P}$ counts in phospholipids separated by thin-layer chromatography

\begin{tabular}{|c|c|c|c|c|}
\hline & Cardiolipin & $\begin{array}{l}\text { Phosphatidyl } \\
\text { glycerol }\end{array}$ & $\begin{array}{l}\text { Phosphatidyl } \\
\text { ethanolamine }\end{array}$ & $\begin{array}{l}\text { Phosphatidyl } \\
\text { serine }\end{array}$ \\
\hline Exponential bacteria & 0.60 & 25.0 & 74.40 & $\ldots * *$ \\
\hline Stationary bacteria & $5 \cdot 37$ & 1473 & $79 \cdot 90$ & -* \\
\hline $\begin{array}{l}\text { Filaments after } 60 \mathrm{~min} \text {. } \\
\text { of penicillin action }\end{array}$ & $5 \cdot 82$ & $16 \cdot 20$ & $76 \cdot 50$ & $I \cdot 68$ \\
\hline $\begin{array}{l}\text { Filaments after } 60 \mathrm{~min} \text {. } \\
\text { of penicillin }+50 \mathrm{~min} \text {. of } \\
\text { penicillinase }\end{array}$ & I.34 & $24 \cdot 40$ & $73 \cdot 0$ & $I \cdot 26$ \\
\hline
\end{tabular}

The values given in Table $I$ are in good agreement both with the results of Lubochinski et al. (I965) who found about $20 \%$ of phosphatidyl glycerol and I.5 to $3.0 \%$ of cardiolipin in exponential Escherichia coli, and with the observations of Kanfer \& Kennedy (I963) who found $21 \%$ of phosphatidyl glycerol in exponential organisms and $7 \%$ in stationary organisms of the same species.

In dividing filaments treated with penicillinase the relative amount of phosphatidyl glycerol increased markedly and after $50 \mathrm{~min}$. it was similar to that of exponentially growing cells. The content of cardiolipin also decreased gradually. Table 2 shows the results obtained with extracts when precipitation with perchloric acid was omitted. No substantial differences in relative amounts of individual phospholipids which could be attributed to the method of extraction were found. Nevertheless, all samples treated with perchloric acid before extraction contained more phosphatidyl serine.

Composition of phospholipids from u.v.-irradiated Escherichia coli. Exponentially growing Escherichia coli $\mathrm{B}$ in GL medium containing $2 \mu \mathrm{C}\left(\left[{ }^{32} \mathrm{P}\right] / \mathrm{ml}\right.$. was irradiated by u.v. and incubated for $60 \mathrm{~min}$. in the dark while shaking. The majority of cells had by then formed filaments. The extract of $\mathrm{HClO}_{4}$-precipitated cells was chromatographed and it contained $3.11 \%$ of cardiolipin, $14.07 \%$ of phosphatidyl glycerol, $77.6 \%$ of phosphatidyl ethanolamine and $5.19 \%$ of phosphatidyl serine, values typical of stationary rather than exponential bacteria, cf. Table 1 . Thus it appears that the inhibition of division by u.v. had similar effect on relative content of phospholipids as had inhibition by penicillin. 


\section{DISCUSSION}

Differences in the ratio of cardiolipin to phosphatidyl glycerol in exponential and stationary Escherichia coli B were observed earlier by several authors (Kanfer \& Kennedy, 1963; Randle, Albro \& Dittmer, 1969), in E. coli K I2 (Cronan, I968) and in Bacillus megaterium (Bertsch et al. 1969). Another observation in good agreement with our results was reported by Cavard, Rampini, Barbu \& Polonovski (I968). $E$. coli, after $30 \mathrm{~min}$. in a mineral medium with no source of carbon, had a significantly higher content of cardiolipin and lower content of phosphatidyl glycerol; a similar situation was observed in organisms incubated in the same medium containing 1000 units of penicillin $/ \mathrm{ml}$. The present work shows that synthesis of total phospholipids in bacteria treated with penicillin occurs at the same rate as in exponentially growing control organisms even though the ratios of cardiolipin and phosphatidyl glycerol are different. Penicillin may interfere with the turnover of individual phospholipids or, more likely, with their further utilization in the mechanism of division. Phospholipids are not only structural; they are involved in the electron transport chain of mitochondria and bacterial membranes (Bruni \& Racker, I968; White \& Tucker, 1969) and also in the synthesis of the peptidoglycan of the wall (Anderson, Matsuhashi, Haskin \& Strominger, I 965). Isolated phospholipids from membranes of Staphylococcus aureus and Micrococcus lysodeikticus are essential for the synthesis of glucosaminyl-acetylmuramyl-oligopeptide (Dietrich, Colucci \& Strominger, I967).

These observations and our results indicate that phospholipids have a direct rôle in wall synthesis and that their relative amounts reflect the situation of the membrane as far as division is concerned. The participation of phospholipids in mucopeptide synthesis may be generally valid but the relation between their metabolism and the mechanism of division is far from clear. Logically, two eventualities may be considered. The change in phospholipid ratios observed in our experiments may be the consequence of inhibition of wall synthesis, yet be of secondary importance for the process of division. The inhibition of wall synthesis, e.g. by penicillin, is in fact accompanied by changes in the level of phospholipid metabolism and by inhibition of division. It would not matter whether the inhibition of the wall synthesis were complete or only partial. Alternatively, phospholipids may have a distinct and direct function in the mechanism of division. In that case an intervention in their metabolism could result in inhibition of normal division or, vice versa, in reinitiation of division where this process is arrested.

The authors, on leave from the Department of Microbiology, Charles University, Prague, would like to express their appreciation for the kind hospitality enjoyed in Professor Senez's laboratory and to acknowledge specially the stimulating interchange of ideas with Drs G. Ailhaud and E. Azoulay, who helped them also with preliminary experiments. One of the authors (J. M.) received EMBO and ICRO shortterm fellowships. 


\section{REFERENCES}

Anderson, J. S., Matsuhashi, M., Haskin, M. A. \& Strominger, J. L. (I965). Lipid-phosphoacetylmuramyl-pentapeptide and lipid-phosphodisaccharide-pentapeptide: presumed membrane transport intermediates in cell wall synthesis. Proceedings of the National Academy of Sciences of the United States of America 53, $88 \mathrm{I}$.

BARTLETT, G. R. (1958). Phosphorus assay in column chromatography. Journal of Biological Chemistry 234, 466 .

BertsCH, L. L., Bonsen, P. P. M. \& KornberG, A. (1969). Biochemical studies of bacterial sporulation and germination. XIV. Phospholipids in Bacillus megaterium. Journal of Bacteriology 98, 75.

BRUNI, A. \& RACKER, E. (I968). Resolution and reconstitution of the mitochondrial electron transport system. I. Reconstitution of the succinate-ubiquinone reductase. Journal of Biological Chemistry 243, 962.

Cavard, D., Rampini, C., Barbu, E. \& Polonovski, J. (1968). Activité phospholipasique et autres modifications du métabolisme des phospholipides consécutives à l'action des colicines sur $E$. coli. Bulletin de la Société de Chimie Biologique 50, 1455.

Cronan, J. E. (1968). Phospholipid alterations during growth of Escherichia coli. Journal of Bacterio$\log y$ 95, 2054.

Dietrich, C. P., Colucci, A. V. \& Strominger, J. L. (i967). Biosynthesis of the peptidoglycan of bacterial cell walls. V. Separation of protein and lipid components of the particulate enzyme from Micrococcus lysodeikticus and purification of the endogenous lipid acceptors. Journal of Biological Chemistry 242, 3218.

DitTMER, J. C. \& Lester, R. L. (1964). A simple, specific spray for the detection of phospholipids on thin-layer chromatography. Journal of Lipid Research $5,126$.

Folch, J., Lees, M. \& Sloan-Stanley, G. H. (1957). A simple method for the isolation and purification of total lipids from animal tissues. Journal of Biological Chemistry 226, 497.

Kanemasa, Y., Akamatsu, Y. \& Nojima, S. (1967). Composition and turnover of the phospholipids in Escherichia coli. Biochimica et Biophysica Acta 144, 382.

KANFER, J. \& KenNEDy, E. P. (1963). Metabolism and function of bacterial lipids. I. Metabolism of phospholipids in Escherichia coli B. Journal of Biological Chemistry 238, 2919.

Lubochinski, B., Meury, J. \& Stolkowski, J. (I965). Transport du potassium et synthèse des phospholipides chez l'Escherichia coli. I. Les phospholipides des souches B I63 et B 525. Bulletin de la Société de Chimie Biologique 47, I529.

Randle, C. L., Albro, P. W. \& Dittmer, J. C. (1969). The phosphoglyceride composition of gramnegative bacteria and the changes in composition during growth. Biochimica et Biophysica Acta I87, 214 .

Rouser, G. \& FleISCHER, S. (1967). Isolation, characterization and determination of polar lipids of mitochondira. Methods in Enzymology, ro, 388.

StÁrka, J. \& MoravovÁ, J. (I967). Cellular division of penicillin-induced filaments of Escherichia coli. Folia Microbiologica, Praha 12, 240.

White, D. C. \& TuCKER, A. N. (I969). Phospholipid metabolism during changes in the proportions of membrane-bound respiratory pigments in Haemophilus parainfluenzae. Journal of Bacteriology 97, 199. 